DOI: https://doi.org/10.36910/6775-2524-0560-2020-41-05

UDC: 517.938

Hubal Halyna M., Ph.D. (Physical and Mathematical Sciences), Associate Professor.

Lutsk National Technical University, Lutsk, Ukraine

\title{
CONSTRUCTION AND STUDY OF THE SYSTEM OF DIFFERENTIAL EQUATIONS THAT DESCRIBES THE MUTUAL SYNCHRONIZATION OF COUPLED SELF-OSCILLATING CHEMICAL SYSTEMS
}

Губаль Г.М. Побудова та дослідження системи диференціальних рівнянь, яка описус взаємну синхронізацію зв'язаних автоколивальних хімічних систем. У статті побудовано та досліджено систему диференціальних рівнянь, яка описує взаємну синхронізацію зв'язаних автоколивальних хімічних систем, визначено полосу синхронізації, в якій існує синхронний режим та визначено час встановлення синхронної різниці фаз.

Ключові слова: автоколивальна система, полоса синхронізації, система диференціальних рівнянь.

Губаль Г.Н. Построение и исследование системы дифференциальных уравнений, описывающей взаимную синхронизацию связанных автоколебательных химических систем. В статье построено и исследовано систему дифференциальных уравнений, описывающей взаимную синхронизацию связанных автоколебательных химических систем, определено полосу синхронизации, в которой существует синхронный режим и определено время установки синхронной разности фаз.

Ключевые слова: автоколебательная система, полоса синхронизации, система дифференциальных уравнений.

Hubal H.M. Construction and study of the system of differential equations that describes the mutual synchronization of coupled self-oscillating chemical systems. The article constructs and investigates the system of differential equations that describes the mutual synchronization of coupled self-oscillating chemical systems, defines the synchronization bar in which a synchronous mode exists and determines the time of establishment of the synchronous phase difference.

Keywords: self-oscillating system, synchronization bar, system of differential equations.

Formulation of the scientific problem. Often there are chemical reactions that occur in an oscillating mode. Mathematical research is needed to describe these reactions. The need to study the mutual synchronization of coupled self-oscillating chemical systems is especially important when applied to biochemical processes in living organisms [1], [2].

Research analysis. We have two diffusely connected self-oscillating systems with oscillating chemical reactions of substances $P$ and $Q$, that are close to harmonic ones. Suppose that, in the absence of a connection between systems I and II, the reactions in them go with the same amplitudes and slightly different frequencies $\omega_{\mathrm{I}}$ and $\omega_{\mathrm{II}}$. Consider the self-oscillating reactions in these chemical systems in the connection between them through diffusion. Diffusion passes from volume $V_{\mathrm{I}}$ to volume $V_{\mathrm{II}}$ and vice versa. We believe that the reactions go with complete stirring.

Presentation of the main material and the justification of the obtained research results.

Denote by $P_{\mathrm{I}}$ and $Q_{\mathrm{I}}$ the concentrations of substances $P$ and $Q$ in volume $V_{\mathrm{I}}, P_{\mathrm{II}}$ and $Q_{\mathrm{II}}$ the concentrations of substances $P$ and $Q$ in volume $V_{\mathrm{II}}$. The flow of a substance $Q$ from one system to another depends on the difference in concentrations $Q_{\mathrm{I}}$ and $Q_{\mathrm{II}}$.

Let the substance $P$ not diffuse from system to system.

Then we describe the self-oscillating chemical reactions in two coupled systems by the following system of differential equations [3]-[7]:

$$
\left\{\begin{array}{l}
\frac{d p_{\mathrm{I}}}{d t}=q_{\mathrm{I}}, \\
\frac{d q_{\mathrm{I}}}{d t}=\mu f_{\mathrm{I}}\left(p_{\mathrm{I}}, q_{\mathrm{I}}\right)-\omega_{\mathrm{I}}^{2} p_{\mathrm{I}}-\lambda\left(q_{\mathrm{I}}-q_{\mathrm{II}}\right), \\
\frac{d p_{\mathrm{II}}}{d t}=q_{\mathrm{II}}, \\
\frac{d q_{\mathrm{II}}}{d t}=\mu f_{\mathrm{II}}\left(p_{\mathrm{II}}, q_{\mathrm{II}}\right)-\omega_{\mathrm{II}}^{2} p_{\mathrm{II}}-\lambda\left(q_{\mathrm{II}}-q_{\mathrm{I}}\right),
\end{array}\right.
$$

where $p_{\mathrm{I}}, p_{\mathrm{II}}, q_{\mathrm{I}}, q_{\mathrm{II}}$ are small deviations from stationary (equilibrium) concentrations $\bar{P}_{\mathrm{I}}, \bar{P}_{\mathrm{II}}, \bar{Q}_{\mathrm{I}}, \bar{Q}_{\mathrm{II}}$ respectively, that is 


$$
\begin{aligned}
& P_{\mathrm{I}}(t)=\bar{P}_{\mathrm{I}}+p_{\mathrm{I}}(t), \\
& Q_{\mathrm{I}}(t)=\bar{Q}_{\mathrm{I}}+q_{\mathrm{I}}(t),
\end{aligned}
$$

similarly it is for $P_{\mathrm{II}}(t)$ and $Q_{\mathrm{II}}(t)$.

Note that

$$
\frac{d q_{\mathrm{I}}(t)}{d t}=\frac{d Q_{\mathrm{I}}(t)}{d t}
$$

since

$$
\frac{d Q_{\mathrm{I}}(t)}{d t}=\frac{d}{d t}\left(\bar{Q}_{\mathrm{I}}+q_{\mathrm{I}}(t)\right)=\frac{d q_{\mathrm{I}}(t)}{d t}
$$

because $\frac{d \bar{Q}_{\mathrm{I}}}{d t}=0$, and $\bar{Q}_{\mathrm{I}}$ does not change over time.

Similarly it is for $\frac{d p_{\mathrm{I}}(t)}{d t}, \frac{d p_{\mathrm{II}}(t)}{d t}, \frac{d q_{\mathrm{II}}(t)}{d t}$.

Let $\bar{P}_{\mathrm{I}}=\bar{P}_{\mathrm{II}}, \bar{Q}_{\mathrm{I}}=\bar{Q}_{\mathrm{II}}$, then the diffusion from system I to system II takes place only due to the differences in concentrations created by self-oscillations $P$ and $Q$ near their stationary levels.

Terms with a multiplier $\lambda$ take into account the diffusion relation, where $\lambda$ is the diffusion relation coefficient, i.e., $\lambda\left(q_{\mathrm{I}}-q_{\mathrm{II}}\right)$ indicates that the rate $\frac{d q_{\mathrm{I}}}{d t}$ of synthesis of the substance $Q$ into $V_{\mathrm{I}}$ decreases due to the outflow of the substance $Q$ from the first system (decrease in its concentration $-q_{\mathrm{I}}$ ) into the second one and the inflow of the same substance $Q$ from the second system (increase in its concentration $+q_{\mathrm{II}}$ ) into the first one.

Since the systems differ only in frequency, then $f_{\mathrm{I}}=f_{\mathrm{II}}$.

The solution of the system of differential equations (1) is sought in the form:

$$
\left\{\begin{array}{l}
p_{\mathrm{I}}(t)=a_{\mathrm{I}}(t) \cos \left(\omega t+\varphi_{\mathrm{I}}\right), \\
q_{\mathrm{I}}(t)=-\omega a_{\mathrm{I}}(t) \sin \left(\omega t+\varphi_{\mathrm{I}}\right), \\
p_{\mathrm{II}}(t)=a_{\mathrm{II}}(t) \cos \left(\omega t+\varphi_{\mathrm{II}}\right), \\
q_{\mathrm{II}}(t)=-\omega a_{\mathrm{II}}(t) \sin \left(\omega t+\varphi_{\mathrm{II}}\right) .
\end{array}\right.
$$

Substituting the solution (2) into the system of differential equations (1), we find:

$$
\left\{\begin{array}{l}
\frac{d a_{\mathrm{I}}}{d t}=\psi_{\mathrm{I}}\left(a_{\mathrm{I}}, a_{\mathrm{II}}, \varphi_{\mathrm{I}}, \varphi_{\mathrm{II}}, t\right), \\
\frac{d a_{\mathrm{II}}}{d t}=\psi_{\mathrm{II}}\left(a_{\mathrm{I}}, a_{\mathrm{II}}, \varphi_{\mathrm{I}}, \varphi_{\mathrm{II}}, t\right), \\
\frac{d \varphi_{\mathrm{I}}}{d t}=\theta_{\mathrm{I}}\left(a_{\mathrm{I}}, a_{\mathrm{II}}, \varphi_{\mathrm{I}}, \varphi_{\mathrm{II}}, t\right), \\
\frac{d \varphi_{\mathrm{II}}}{d t}=\theta_{\mathrm{II}}\left(a_{\mathrm{I}}, a_{\mathrm{II}}, \varphi_{\mathrm{I}}, \varphi_{\mathrm{II}}, t\right) .
\end{array}\right.
$$

The formulas of the functions $\psi_{\mathrm{I}}, \psi_{\mathrm{II}}, \theta_{\mathrm{I}}, \theta_{\mathrm{II}}$ are quite cumbersome. To simplify them, we can take into account that since the frequencies $\omega_{\mathrm{I}}$ and $\omega_{\mathrm{II}}$ have similar values, then they can be written as $\omega=\omega_{\mathrm{I}}=\omega_{\mathrm{II}}$. Since the amplitudes $a_{\mathrm{I}}(t)$ and $a_{\mathrm{II}}(t)$ for the period $T=\frac{2 \pi}{\omega}$ vary very little, then in $\psi_{\mathrm{I}}, \psi_{\mathrm{II}}, \theta_{\mathrm{I}}, \theta_{\mathrm{II}}$ under the integral signs, these amplitudes can be considered constant values and can be taken outside the integral signs. 
Taking into account that the synchronicity conditions can approximately be obtained from the differential equations for the phases of the system (3), the differential equations for phases after all simplifications take the form:

$$
\begin{aligned}
& \frac{d \varphi_{\mathrm{I}}}{d t}=-\frac{\lambda}{2} \cdot \frac{a_{\mathrm{II}}}{a_{\mathrm{I}}} \sin \left(\varphi_{\mathrm{I}}-\varphi_{\mathrm{II}}\right)-\frac{\omega^{2}-\omega_{\mathrm{I}}^{2}}{2 \omega}, \\
& \frac{d \varphi_{\mathrm{II}}}{d t}=\frac{\lambda}{2} \cdot \frac{a_{\mathrm{I}}}{a_{\mathrm{II}}} \sin \left(\varphi_{\mathrm{I}}-\varphi_{\mathrm{II}}\right)-\frac{\omega^{2}-\omega_{\mathrm{II}}^{2}}{2 \omega}
\end{aligned}
$$

In a combined diffusely coupled self-oscillating system, the oscillating process goes with one frequency $\omega$. This synchronization condition is fulfilled automatically if the difference of phases $\varphi_{\mathrm{I}}-\varphi_{\mathrm{II}}$ that change slowly over time tends to a constant value.

Let us prove when it is possible.

We subtract the differential equation (5) from the differential equation (4):

$$
\frac{d\left(\varphi_{\mathrm{I}}-\varphi_{\mathrm{II}}\right)}{d t}=-\frac{\lambda}{2} \cdot\left(\frac{a_{\mathrm{II}}}{a_{\mathrm{I}}}+\frac{a_{\mathrm{I}}}{a_{\mathrm{II}}}\right) \sin \left(\varphi_{\mathrm{I}}-\varphi_{\mathrm{II}}\right)+\frac{\omega_{\mathrm{I}}^{2}-\omega_{\mathrm{II}}^{2}}{2 \omega} .
$$

Since $\omega \approx \omega_{\mathrm{I}} \approx \omega_{\mathrm{II}}$, then $\omega_{I}-\omega_{\mathrm{II}}=\delta \ll \omega$. Therefore,

$$
\frac{\omega_{\mathrm{I}}^{2}-\omega_{\mathrm{II}}^{2}}{2 \omega}=\frac{\left(\omega_{\mathrm{I}}-\omega_{\mathrm{II}}\right)\left(\omega_{\mathrm{I}}+\omega_{\mathrm{II}}\right)}{2 \omega} \approx \omega_{\mathrm{I}}-\omega_{\mathrm{II}}=\delta .
$$

Taking into account that $a_{\mathrm{I}} \approx a_{\mathrm{II}}$, we can write

$$
\frac{a_{\mathrm{II}}}{a_{\mathrm{I}}}+\frac{a_{\mathrm{I}}}{a_{\mathrm{II}}}=2
$$

Then the differential equation (6) takes the form:

$$
\frac{d\left(\varphi_{\mathrm{I}}-\varphi_{\mathrm{II}}\right)}{d t}=\delta-\lambda \sin \left(\varphi_{\mathrm{I}}-\varphi_{\mathrm{II}}\right)
$$

We find a stationary solution of this differential equation. We write

$$
\frac{d\left(\varphi_{\mathrm{I}}-\varphi_{\mathrm{II}}\right)}{d t}=0
$$

Then

$$
\delta-\lambda \sin \left(\bar{\varphi}_{\mathrm{I}}-\bar{\varphi}_{\mathrm{II}}\right)=0
$$

whence

$$
\sin \left(\bar{\varphi}_{\mathrm{I}}-\bar{\varphi}_{\mathrm{II}}\right)=\frac{\delta}{\lambda}
$$

Since $\left|\sin \left(\bar{\varphi}_{\mathrm{I}}-\bar{\varphi}_{\mathrm{II}}\right)\right| \leq 1$, then $\left|\frac{\delta}{\lambda}\right| \leq 1$ or, taking into account that $\lambda>0,|\delta| \leq \lambda$, or $\left|\omega_{\mathrm{I}}-\omega_{\mathrm{II}}\right| \leq \lambda$.

Therefore, the synchronous mode exists only in the synchronization bar that corresponds to the formula $\left|\omega_{\mathrm{I}}-\omega_{\mathrm{II}}\right| \leq \lambda$

Let's estimate time of establishment of the synchronous mode at $\left|\bar{\varphi}_{\mathrm{I}}-\bar{\varphi}_{\mathrm{II}}\right| \square \frac{\pi}{2}$. Then $\sin \left(\varphi_{\mathrm{I}}-\varphi_{\mathrm{II}}\right) \approx \varphi_{\mathrm{I}}-\varphi_{\mathrm{II}}$, and the differential equation (7) takes the form:

$$
\frac{d\left(\varphi_{\mathrm{I}}-\varphi_{\mathrm{II}}\right)}{d t}=\delta-\lambda\left(\varphi_{\mathrm{I}}-\varphi_{\mathrm{II}}\right)
$$


Let us solve this non-homogeneous differential equation. First, we find the general solution of the corresponding homogeneous differential equation:

$$
\frac{d\left(\varphi_{\mathrm{I}}-\varphi_{\mathrm{II}}\right)}{d t}=-\lambda\left(\varphi_{\mathrm{I}}-\varphi_{\mathrm{II}}\right)
$$

Its general solution has the form

$$
\varphi_{\mathrm{I}}-\varphi_{\mathrm{II}}=C e^{-\lambda t}
$$

We write the general solution of the non-homogeneous differential equation (8) in the form

$$
\varphi_{\mathrm{I}}-\varphi_{\mathrm{II}}=C(t) e^{-\lambda t} .
$$

Find the function $C(t)$, substituting the general solution (9) into the non-homogeneous differential equation (8):

$$
C(t) e^{-\lambda t}(-\lambda)+\frac{d C(t)}{d t} e^{-\lambda t}=\delta-\lambda\left(\varphi_{\mathrm{I}}-\varphi_{\mathrm{II}}\right)
$$

or

$$
-\lambda C(t) e^{-\lambda t}+\frac{d C(t)}{d t} e^{-\lambda t}=\delta-\lambda C(t) e^{-\lambda t}
$$

or

$$
\frac{d C(t)}{d t}=\delta e^{\lambda t}
$$

whence

$$
C(t)=\int \delta e^{\lambda t} d t
$$

or

$$
C(t)=\frac{\delta}{\lambda} e^{\lambda t}-C_{1}
$$

Then

$$
\varphi_{\mathrm{I}}-\varphi_{\mathrm{II}}=\left(\frac{\delta}{\lambda} e^{\lambda t}-C_{1}\right) e^{-\lambda t}
$$

or

$$
\varphi_{\mathrm{I}}-\varphi_{\mathrm{II}}=\frac{\delta}{\lambda}-C_{1} e^{-\lambda t}
$$

Substituting initial data: for $t=0, \varphi_{\mathrm{I}}-\varphi_{\mathrm{II}}=\varphi_{\mathrm{I} 0}-\varphi_{\mathrm{II} 0}$ into the equation (10), we find $C_{1}$ :

$$
\varphi_{\mathrm{I} 0}-\varphi_{\mathrm{II} 0}=\frac{\delta}{\lambda}-C_{1} \cdot 1,
$$

whence

$$
C_{1}=\frac{\delta}{\lambda}-\left(\varphi_{\mathrm{I} 0}-\varphi_{\mathrm{II} 0}\right)
$$

Substituting $C_{1}$ into the equation (10), we find the difference of phases:

$$
\varphi_{\mathrm{I}}-\varphi_{\mathrm{II}}=\frac{\delta}{\lambda}-\left(\frac{\delta}{\lambda}-\left(\varphi_{\mathrm{I} 0}-\varphi_{\mathrm{II} 0}\right)\right) e^{-\lambda t}
$$


or

$$
\varphi_{\mathrm{I}}-\varphi_{\mathrm{II}}=\left(\varphi_{\mathrm{I} 0}-\varphi_{\mathrm{II} 0}-\frac{\delta}{\lambda}\right) e^{-\lambda t}+\frac{\delta}{\lambda}
$$

where $\varphi_{\mathrm{I} 0}-\varphi_{\mathrm{II} 0}$ is the difference of the initial phases.

From the formula (11) as $t \rightarrow \infty$, we obtain

$$
\varphi_{\mathrm{I}}-\varphi_{\mathrm{II}} \rightarrow \bar{\varphi}_{\mathrm{I}}-\bar{\varphi}_{\mathrm{II}}=\frac{\delta}{\lambda}
$$

From the formula (11), we take into account that the time for which the exponential function decreases by $e$ times is denoted by the time $\tau$ of establishment of the synchronous phase difference:

$$
\lambda \tau=1 \quad \text { or } \quad \tau=\frac{1}{\lambda}
$$

If one of these chemical systems has an amplitude greater (more powerful) than the other, then as a result of diffusion it will synchronize the other imposing its frequency on it. Then this more powerful chemical system can be considered as a generator, an "external force" that synchronizes.

The basic laws of synchronization in relaxation systems, in which the form of oscillations is far from sinusoidal, remain the same as in almost sinusoidal ones. Unlike sinusoidal systems, relaxation systems (which are also common in chemistry and biology) have significantly less time $\tau$ to establish synchronism. Synchronization can also take place in multiple tones. For example, a generator with frequency $\omega_{\text {I }}$ may be synchronized with a generator with frequency $2 \omega_{\mathrm{II}}$ where $\omega_{\mathrm{I}} \approx \omega_{\mathrm{II}}$. A powerful synchronizing system that sets the rhythm for all other systems is a biological clock.

One example in a living system is the synchronization of heart muscle fiber contractions.

Conclusions and prospects for further research. A system of differential equations is constructed and investigated, which describes the mutual synchronization of coupled self-oscillating chemical systems.

The synchronization bar in which the synchronous mode exists is defined.

The time of establishment of the synchronous phase difference is determined.

Further research can be done for cases of occurrence of self-oscillating chemical reactions of random changes in the concentrations of reactants in the space.

\section{Список бібліографічного опису}

1. Дж. Тайсон (2002) Біохімічні коливання. Computational Cell Biology, № 20, С. 230-260.

2. Б. Новак, Дж. Тайсон (2008) Принципи побудови біохімічних осциляторів. Nature Reviews. Molecular Cell Biology, т.

9, № 12, С. 981-991.

3. Б. Демидович, В. Моденов (2008) Дифференцииальные уравнения. 3-е изд., Санкт-Петербург: Лань.

4. Г.Н. Губаль (2015) Междисциплинарные связи в дифференциальной модели исследования колебаний в биологических системах. В трудах Международной математической конференции “Шестые Богдановские чтения по обыкновенным дифференциальным уравнениям", С. 142-144.

5. Г.М. Губаль (2017) Побудова та дослідження системи диференціальних рівнянь, яка описує швидкості біохімічних процесів. Комп 'ютерно-інтегровані технології: освіта, наука, виробництво, № 27, С. 99-104.

6. А. Стразерс, М. Поттер (2019) Диферениіальні рівняння: для науковиів та інженерів. 2-ге вид., Springer.

7. Д.Г. Зілл (2017) Перший курс з диференціальних рівнянь з додатками для моделювання. 11-те вид., Cengage Learning.

\section{References}

1. Tyson, J. (2002) Biochemical oscillations. Computational Cell Biology, no. 20, P. 230-260.

2. Novak, B. \& Tyson, J. (2008) Design principles of biochemical oscillators. Nature Reviews. Molecular Cell Biology, vol. 9 , no. 12, P. 981-991.

3. Demidovich, B. \& Modenov, V. (2008) Differential Equations. 3rd ed., Saint Petersburg: Lan.

4. Hubal, H. M. (2015) Interdisciplinary connections in a differential research model of oscillations in biological systems. In Proceedings of International Mathematical Conference "Shesty'e Bogdanovskie chteniya po oby'knovenny'm differenczial'ny'm uravneniyam", P. 142-144.

5. Hubal, H. M. (2017) The construction and study of the system of differential equations that describes biochemical processes rates. Computer Integrated Technologies: Education, Science, Production, no. 27, P. 99-104.

6. Struthers, A. \& Potter, M. (2019) Differential equations: for scientists and engineers. 2nd ed., Springer.

7. Zill, D.G. (2017) A first course in differential equations with modeling applications. 11th ed., Cengage Learning. 